\title{
Quality of life regarding the health of people with diabetes mellitus type 2
}

\author{
Qualidade de vida relacionada à saúde de pessoas com diabetes mellitus tipo 2 \\ Calidad de vida relacionada a la salud de personas con diabetes mellitus tipo 2
}

Loisláyne Barros Leal ${ }^{1}$, Ionara Holanda Moura ${ }^{2}$, Rumão Batista Nunes de Carvalho ${ }^{3}$, Nahadja Tahaynara Barros Leal $^{4}$, Anael Queirós Silva ${ }^{3}$, Ana Roberta Vilarouca da Silva ${ }^{3}$

The objective of this study was to evaluate the quality of life related to the health of people with diabetes mellitus type 2. It was a cross-sectional research conducted with 100 diabetics. Data collection was conducted during March and April 2012 with two teams of the Family Health Strategy in Picos, PI, Brazil through individual interviews. A form containing socioeconomic, clinical and the Medical Outcomes Study 36 - Item Short Form Health Survey (SF-36). The average among the participants of the SF-36 ranged from 34.8 (physical aspects) to 72.0 (mental health). There was a statistically significant association between pain and functional capacity with sex, as well as functional capacity and emotional aspects with physical activity $(\mathrm{p}<0.05)$. It was concluded that the participants had a better quality of life in the assessment in the dimensions that comprise mental components.

Descriptors: Quality of Life; Chronic Disease; Diabetes Mellitus, Type 2.

Objetivou-se avaliar a Qualidade de Vida Relacionada à Saúde de pessoas com Diabetes Mellitus tipo 2. Pesquisa transversal realizada com 100 diabéticos. A coleta dos dados foi realizada nos meses de março e abril de 2012, em duas equipes da Estratégia Saúde da Família de Picos, PI, Brasil por meio de entrevista individual. Aplicou-se um formulário contendo variáveis socioeconômicas, clínicas e o Medical Outcomes Study 36 - Item Short Form Health Survey (SF-36). As médias entre os componentes do SF-36 variaram de 34,8 (Aspectos físicos) a 72,0 (Saúde mental). Houve associação estatisticamente significante da dor e capacidade funcional com o sexo, bem como, da capacidade funcional e aspectos emocionais com a atividade física $(\mathrm{p}<0,05)$. Conclui-se que os participantes apresentaram uma melhor avaliação na qualidade de vida nas dimensões que integram o componente mental.

Descritores: Qualidade de Vida; Doença Crônica; Diabetes Mellitus Tipo 2.

El objetivo fue evaluar la Calidad de Vida Relacionada a la Salud de personas con Diabetes Mellitus tipo 2. Investigación transversal, realizada con 100 diabéticos. La recolección de datos se llevó a cabo entre marzo y abril de 2012, en dos equipos de la Estrategia Salud de la Familia de Picos, PI, Brasil, a través de entrevista individual. Se aplicó formulario con variables socioeconómicas, clínicas y el Medical Outcomes Study 36 - Item Short Form Health Survey (SF-36). El promedio entre los componentes del SF-36 osciló de 34,8 (Aspectos físicos) a 72,0 (Salud mental). Hubo asociación estadísticamente significativa del dolor y la capacidad funcional con el sexo, así como de la capacidad funcional y los aspectos emocionales con la actividad física $(\mathrm{p}<0,05)$. En conclusión, los participantes presentaron mejor evaluación en la calidad de vida en las dimensiones que integran el componente mental.

Descriptores: Calidad de Vida; Enfermedad Crónica; Diabetes Mellitus Tipo 2.

\footnotetext{
${ }^{1}$ Instituto do Rim. Picos, PI, Brazil.

${ }^{2}$ Estratégia Saúde da Família de Demerval Lobão. Demerval Lobão, PI, Brazil.

${ }^{3}$ Universidade Federal do Piauí. Teresina, PI, Brazil.

${ }^{4}$ Universidade Federal de Campina Grande. Campina Grande, PB, Brazil.
}

Corresponding author: Ana Roberta Vilarouca da Silva

Rua Cícero Eduardo, 905. Junco. Picos-PI. CEP: 64600-000. Teresina, PI, Brazil. E-mail: robertavilarouca@yahoo.com.br 


\section{Introduction}

Diabetes mellitus is a disease of incidence and growing prevalence among the population ${ }^{(1)}$, and diabetes mellitus type 2 is the most predominant form in $90 \%$ to $95 \%$ of the cases ${ }^{(2)}$. According to an estimate by the International Diabetes Federation, the current 284 million with diabetes type 2 will increase in more than $50 \%$ in the next 20 years, thus constituting a potential problem in public health and growing incidence worldwide ${ }^{(3)}$.

In general the population aging, and the growing organization, sedentary in life, the hypo-caloric diets and obesity are the great responsible factors for the increase of prevalence of such disease, configuring it today, a worldwide epidemics. Four million deaths a year in the world are determined by this pathology and its complications ${ }^{(4)}$.

One of the great economic impacts of this disease occurs in the health services, resulting from the costs of the treatment, especially of their cardiovascular complications, dialysis from renal chronic insufficiency, as well as from amputations of the limbs ${ }^{(4)}$, besides the State costs resulting from early retirement due to functional incapability brought by their complications ${ }^{(5)}$.

As a chronical condition, the diabetes requires from the person attacked with this disease, the assistance of a therapy regime of daily self-care, which is necessary to maintain the metabolic control.

This need of adaptation, added to the chronical condition can act negatively influencing in the quality of life of those people. A Brazilian study showed that patients with diabetes mellitus have lower levels of quality of life than other people who have not been attacked by the disease ${ }^{(6)}$.

Another study showed that several factors can influence the quality of life, highlighting the type of diabetes, use of insulin, age, chronical complications, socioeconomic and educational level, psychological factors, knowledge on the disease and access and type of the assistance received ${ }^{(7)}$.
The quality of life concerning health has been used in the area to differentiate the quality of life in a generic sense. It is considered a synonym of the term 'condition of health perceived', which contains three large domains: physical, psychological and social ${ }^{(8)}$. This thematic emerges in the scenario of the researches as a new possibility of directing the practices in health, especially in basic care, once it is an entrance door to the actions and services. So, the study of the quality of life related to health makes feasible the creation of strategies and effective programs of intervention for the promotion of the integrality of care to the bearers of diabetes mellitus type $2^{(9)}$.

According to the above mentioned, the present study was aimed at evaluating the quality of life related to the health of patients with diabetes mellitus type 2 assisted in the Family Health Strategy.

\section{Method}

This is a cross-sectional study, developed in two Family Health Units, in the city of Picos, PI, Brazil, selected at random through draw.

Of the 166 people with diagnosis in the diabetes mellitus type 2 assisted in the health units, who were registered in the high Hiperdia programme at the current moment of data collection; 100 diabetic patients took part in this study, who contemplate the criteria of inclusion established as follows: age above 40 years, by convenience, due to the fact that they belonged to the age range which was more frequently present at the health units, and for having diagnosis of diabetes mellitus type 2. People who presented incapability of verbal communication, identified by the researcher at the moment of the interview, were excluded of the research.

The data collection was made in March and April of 2012, through individual interview, using a form containing socioeconomic and clinical variables. An instrument was also used to evaluate the quality of life, the Medical Outcomes Study 36 - Item Short Form Health Survey (SF-36) ${ }^{(10)}$ in a translated, adapted and 
valid version for Brazil ${ }^{(11)}$.

The SF-36 is a generic scale of evaluation of the quality of life made by 36 items distributed in eight components: functional Capacity, physical aspects, pain, general condition of health, vitality, social aspects, emotional aspects and mental health and one more question which promotes the comparison of the current general condition of health to the one, one year ago. These categories can still be analyzed in briefing measures called 'physical condition and mental condition'(11).

The application of the SF-36 allows to obtain the data concerning the last four weeks and evaluates both negative points of health (disease/infirmity) as well as positive ones (welfare) of the subject. And it presents a final score which varies in a range from 0 (the worst general condition of health) to 100 (best general condition of health), and each one of the dimensions were separately evaluated ${ }^{(10-12)}$.

The data were distributed and ordinated through Excel 8.0 software and afterwards processed in the Statistical Package for the Social Science version 17.0. The social demographic variables related to the diabetes were analyzed through the means of a simple distribution of frequency, for the variable categories (dimensions of the SF-36) mean and median was used, for the numerical a standard deviation. To compare the quality of life with sex, practice of physical activity and number of comorbidities the ANOVA-F ( $<<0.05)$ was used. Each domain of the WHOQOL-BREF was isolated analyzed, in the Statistical Package for the Social Sciences software, which are respective syntaxes.

The study was made after the approval of the Committee of Ethics in Research of Universidade Federal do Piauí, according to protocol no. 0426.0.045.000-11. All the participants signed a free Informed Consent Form in two copies, one was kept by the participant and the by the researcher responsible for the study ${ }^{(13)}$.

\section{Results}

Of the 100 diabetic patients, 59\% were female, the age range was 43 years (Average, 64.1 years). $72 \%$ of the people with diabetes mellitus had been studied between 0 and 6 years, $51 \%$ were married, $86 \%$ were catholic and $55 \%$ were retired.

The main problems reported for the nontreatment in the adequate way were the deficit of knowledge of diabetes (20\%), lack of motivation (19\%), lack of interest (15\%), aversion to specific food $(10 \%)$, lack of family support (12\%) and nonacceptance of the diagnosis (3\%) and a percentage of $35 \%$ reported as other causes such as difficulty of locomotion, financial problems, routine of exhaustive work, body pain, visual deficit, problems of arthroses, osteoporosis and arrhythmia.

The average time of diagnosis of the diabetes mellitus was 8.6 years and the greatest proportion (73\%) of people reporting situations which cause lack of adhesion to the treatment. Hypertension $(n=68)$ was the comorbidity more concomitantly associated to the diabetes and among its complication, the most mentioned $(n=88)$ were the ophthalmological ones (Table 1).

Table 1 - Variables related to diabetes in patients assisted in a Family Health Unit

\begin{tabular}{lc}
\hline Variables & $\mathbf{n ~ ( \% )}$ \\
\hline Time of diagnosis of Diabetes Mellitus & \\
(years) & $13(13.0)$ \\
$\leq 1$ & $52(52.0)$ \\
$2-10$ & $35(35.0)$ \\
$\geq 11$ & \\
(Average = 8.6; Standard deviation = 6.2) & \\
Problem to make the treatment & $73(73.0)$ \\
Yes & \\
Other associated pathology* & $68(41.0)$ \\
Hypertension & $41(24.8)$ \\
Dyslipidemia & $23(13.8)$ \\
Others & $17(10.2)$ \\
Cardiovascular disease & $11(6.6)$ \\
Depression & $6(3.6)$ \\
Obesity & \\
Complications of Diabetes Mellitus* & $82(56.9)$ \\
Ophthalmological & $32(22.2)$ \\
Neuropathic & $16(11.2)$ \\
Pododynia & $10(6.9)$ \\
Kidney & $4(2.8)$ \\
Cardiovascular & \\
*A person can be informed of one or more situations of diabetes mellitus
\end{tabular}


In the evaluation of the quality of life the average standard score for each dimension of the SF36 was obtained, where the values ranged from 34.8 to 72.0 characterizing the highest and the lowest impact of diabetes in the quality of life. Only three dimensions presented an average score value bellow 50 (physical aspects, emotional aspects and general condition of health) corresponding to half of the maximum value which is 100 , thus demonstrating a higher commitment of those components (Table 2).

Table 2 - Evaluation of the quality of the patient with diabetes mellitus assisted in a Family Health Unit

\begin{tabular}{lcc}
\hline Dimensions of SF-36 (items) & Average (SD) & Average \\
\hline Mental health (5) & $72.0(22.6)$ & 78.8 \\
Social aspects (2) & $71.1(25.0)$ & 73.8 \\
Pain (2) & $63.6(31.6)$ & 70.8 \\
Vitality (4) & $63.3(23.6)$ & 63.8 \\
Functional Capacity (10) & $52.2(33.8)$ & 51.0 \\
General condition of health (2) & $49.8(19.3)$ & 50.8 \\
$\begin{array}{l}\text { Emotional aspects (3) } \\
\text { Physical aspects (4) }\end{array}$ & $44.0(29.6)$ & 20.0 \\
\hline $\begin{array}{l}\text { SF-36: Medical Outcomes Study 36-Item Short Form Health Survey DP: Stan- } \\
\text { dard deviation }\end{array}$ &
\end{tabular}

The correlation between sex of the participants and the measures of quality of life regarding health showed that men presented a better evaluations of the components of the SF-36 concerning the women, except in the physical aspect domain, because there was only a significant statistically association with the pain and the functional capacity $(\mathrm{p}<0.05)$ (Table 3$)$.

Among the diabetic patients who practice physical activities there was a better evaluation of the quality of life and all the components related to the one who did not practice it, with a significant statistically relation between the functional capacity and the emotional aspects $(\mathrm{p}<0.05)($ Table 3$)$.
Table 3 - Association of the gender and physical activities with the dimensions of the SF-36 of the people with diabetes mellitus type 2

\begin{tabular}{|c|c|c|c|c|c|c|}
\hline \multirow{3}{*}{$\begin{array}{l}\text { Dimensions } \\
\text { of SF-36 }\end{array}$} & \multicolumn{2}{|c|}{ Gender } & \multirow[b]{2}{*}{$\mathbf{p}$} & \multicolumn{3}{|c|}{ Physical activities } \\
\hline & Male & $\begin{array}{c}\text { Fema- } \\
\text { le }\end{array}$ & & Yes & No & $\mathbf{p}$ \\
\hline & $\begin{array}{c}\mathrm{A} \\
\text { (SD) }\end{array}$ & $\begin{array}{c}A \\
\text { (SD) }\end{array}$ & & $\begin{array}{c}A \\
\text { (SD) }\end{array}$ & $\begin{array}{c}\mathrm{A} \\
\text { (SD) }\end{array}$ & \\
\hline Pain & $\begin{array}{c}77.9 \\
(28.1)\end{array}$ & $\begin{array}{c}53.6 \\
(30.2)\end{array}$ & 0.000 & $\begin{array}{c}78.7 \\
(20.4)\end{array}$ & $\begin{array}{c}68.6 \\
(26.0)\end{array}$ & 0.079 \\
\hline $\begin{array}{l}\text { Mental } \\
\text { Health }\end{array}$ & $\begin{array}{c}77.3 \\
(19.6)\end{array}$ & $\begin{array}{c}68.4 \\
(24.0)\end{array}$ & 0.051 & $\begin{array}{c}78.6 \\
(17.4)\end{array}$ & $\begin{array}{c}69.8 \\
(23.9)\end{array}$ & 0.093 \\
\hline $\begin{array}{l}\text { Physical } \\
\text { Aspects }\end{array}$ & $\begin{array}{c}74.1 \\
(22.6)\end{array}$ & $\begin{array}{c}69.1 \\
(26.6)\end{array}$ & 0.331 & $\begin{array}{c}70.5 \\
(20.7)\end{array}$ & $\begin{array}{c}60.9 \\
(24.1)\end{array}$ & 0.081 \\
\hline Vitality & $\begin{array}{c}67.8 \\
(21.5)\end{array}$ & $\begin{array}{c}60.3 \\
(24.2)\end{array}$ & 0.119 & $\begin{array}{c}65.8 \\
(30.7)\end{array}$ & $\begin{array}{c}47.7 \\
(33.8)\end{array}$ & 0.020 \\
\hline $\begin{array}{l}\text { Functional } \\
\text { Capacity }\end{array}$ & $\begin{array}{c}62.3 \\
(37.7)\end{array}$ & $\begin{array}{c}45.2 \\
(31.2)\end{array}$ & 0.012 & $\begin{array}{c}64.9 \\
(31.7)\end{array}$ & $\begin{array}{c}63.2 \\
(31.8)\end{array}$ & 0.814 \\
\hline $\begin{array}{l}\text { General } \\
\text { condition of } \\
\text { health }\end{array}$ & $\begin{array}{c}50.3 \\
(18.4)\end{array}$ & $\begin{array}{c}49.5 \\
(20.0)\end{array}$ & 0.833 & $\begin{array}{c}51.3 \\
(20.2)\end{array}$ & $\begin{array}{c}49.3 \\
(19.1)\end{array}$ & 0.654 \\
\hline $\begin{array}{l}\text { Emotional } \\
\text { aspects }\end{array}$ & $\begin{array}{c}48.8 \\
(29.9)\end{array}$ & $\begin{array}{c}40.8 \\
(29.1)\end{array}$ & 0.184 & $\begin{array}{c}50.7 \\
(29.7)\end{array}$ & $\begin{array}{c}41.8 \\
(29.4)\end{array}$ & 0.028 \\
\hline $\begin{array}{l}\text { Physical } \\
\text { Aspects }\end{array}$ & $\begin{array}{c}34.4 \\
(26.7)\end{array}$ & $\begin{array}{c}35.0 \\
(25.7)\end{array}$ & 0.909 & $\begin{array}{c}44.6 \\
(27.7)\end{array}$ & $\begin{array}{c}31.5 \\
(24.7)\end{array}$ & 0.198 \\
\hline
\end{tabular}

Concerning the comparison of the current conditions of health and the ones one year ago, 39\% reported to be 'almost the same thing', 27\% reported to feel 'a little worse' and only 19\% consider being 'a little better'.

\section{Discussion}

The diabetes mellitus is considered one of the main current problems of public health, and diabetes mellitus type 2 is the prevalent form among patients with more advanced age. Most of the participants in this research were within 0 to 6 years of study, a fact that can be directly related to the main problems reported by the same for not having adequate treatment, which was the deficit of knowledge on the disease.

The democratization of the knowledge on the health disease process, especially in the scope of the 
chronical diseases is fundamental in order to obtain satisfactory results in the treatment, besides the possibility of choice through health life habits thus contributing to the improvement of quality of life ${ }^{(14)}$.

As to the situation of marital status most of them reported to be married (51\%). The marital status interferes in the adhesion to the treatment, in the family dynamics and in the psychosocial profile influences in the glycemic variations, being the family environment a stimulus to self-care ${ }^{(15)}$.

In this study the evaluation concerning the assistance of the therapeutics showed the need of a better adhesion from the evaluated diabetics patients, especially regarding the healthy habits of life. Although, a significant number of the sampling followed the recommended diet, only $26 \%$ practiced a physical activity, diverging of the preconized and observed behavior in other researches concerning the adherence to this practice, which showed a higher rate $^{(16-18)}$.

The literature refers to the practice of physical activity as a differential aspect highlighting that patients who practice physical activity present a better evaluation of the quality of life. Such practice must be incentivized by the health professionals and there should be interventions pursuing the awareness of the role of the regular practice of physical activity for life ${ }^{(14)}$.

Currently the improvement of the quality of life is directly linked to the practice of physical activity, once the degenerative chronical diseases such as heart diseases, diabetes and hypertension, which present a high rate of maternity, are associated to the inadequate habits and diet and to sedentary life, but people with certain degenerative chronical diseases are not able to practice activities, within their limitations and specific physical conditions ${ }^{(19)}$.

The regular practice of physical activity and the change of habits with the use of self-care practices is fundamental for an adequate management of the disease and the minimization of the complications, the isolated treatment, does not represent a good glycemic control, for such, it is necessary the association of the prescribed medication, adequate diet, regular practice of physical activities and the semester laboratory exams $^{(16)}$

Not following therapy in an adequate way implies in the emergence of chronic complications of the disease, and among the most prevalent in the evaluated sampling the visual problems were highlighted. According to the Brazilian Society of Diabetes $^{(2)}$ diabetic retinopathy is the main cause of blindness in people in their productive age (16 to 64 years), and this is observed in $90 \%$ of the people with diabetes mellitus type and in $60 \%$ of those with diabetes mellitus type 2 .

In person with diabetes mellitus type 2, besides the visual problems, it should be highlighted the raising from two to four times the risks for the development of cardiovascular diseases which are responsible for $75 \%$ of the deaths of the patients with the disease ${ }^{(2)}$. The acute and chronical complications resulting from diabetes are conditioned by factors originated in their own style of life, that is, they are related to the control of glycemic levels reached along treatment ${ }^{(16)}$.

Such complications can influence in the quality of life of the patient, precise other factors, from objective one (conditions of health, earnings, housing) to more subjective ones (humor, self-esteem and selfimage),independently of the specific or global focus to the quality of life (quality of life concerning health) ${ }^{(19)}$.

In a study made with diabetic patients at a Family Health Unit, aiming at accessing the quality of life, the highest scores were obtained in the social aspects (63.8) and pain (53) dimensions, and the lowest average scores were in the emotional aspects (46.6) and physical aspects (38.6) ${ }^{(20)}$.

Otherwise, these findings differ from another investigation where the quality of life of people with diabetes mellitus and/or arterial hypertension using the SF-36 was evaluated, observing that the worst scores were obtained in the general condition of health and functional capacity domains ${ }^{(14)}$.

One of the limitations of this study is concentra- 
ted on the difficulty of understanding, by part of some participants concerning the categories of answer to specific items of the SF-36 instruments, and this difficulty was particularly more expressive concerning question nine, such fact can be related to the low schooling observed in the participants of the sampling.

\section{Conclusion}

The evaluation of the quality of life reports to a holistic vision of aspects, which are liable to interventions, to the nurse, as well as to the multi professional team; it is necessary the effective and complete assistance of the patients with diabetes mellitus type 2 aiming at assisting their biological and psychosocial needs.

Therefore, the use of instruments validated according to SF-36, make a better visualization of the health conditional feasible. In this study, it was identified that the dimensions which obtained the lowest scores were the ones concerning the physical and emotional aspects, the knowledge on those will enable the specific actions turned to these groups in order to promote a better adhesion to practice which positively influence the quality of life.

However, it is still considered important more studies on the thematic, once they are insufficient for the publishing concerning the evaluation of the quality of life of diabetic patients in Brazil, especially in the northeastern region, even facing its importance in directing the specific strategies of care to minimize or prevent its commitment.

\section{Collaborations}

Leal LB, Carvalho RBN, Leal NTB and Silva ARV contributed for the conception and interpretation of findings in the work. Moura IH and Silva AQ contributed for the analysis, interpretation and final writing of the article.

\section{References}

1. Ministério da Saúde (BR). Secretaria de Atenção à Saúde. Departamento de Atenção Básica. Estratégias para o cuidado da pessoa com doença crônica: diabetes mellitus. Brasília: Ministério da Saúde; 2013.

2. Sociedade Brasileira de Diabetes. Diretrizes da Sociedade Brasileira de Diabetes. $3^{3}$ ed. São Paulo: Itapevi; 2009.

3. Godoy-Matos AF. Endocardiometabologia na prática clinica. $1^{\underline{a}}$ ed. Rio de Janeiro: Guanabara Koogan; 2011.

4. Ministério da Saúde (BR). Secretária de Atenção à Saúde. Departamento de Atenção Básica. Coordenação Nacional de Hipertensão e Diabetes. VIGITEL 2009. Brasília: Ministério da Saúde; 2011.

5. Gomes MB, Cobas R. Diabetes mellitus. In: Grossi SAA, Pascali PM. Cuidados de enfermagem em diabetes. São Paulo: Sociedade Brasileira de Diabetes; 2009. p. 6-17.

6. Zulian LR, Santos MA, Veras VS, Rodrigues FFL, Arrelias CCA, Zanetti ML. Quality of life in patients with diabetes using the Diabetes 39 (D-39) instrument. Rev Gaúcha Enferm. 2013; 34(3):13846.

7. Faria HTG, Veras VS, Xavier ATF, Teixeira CRS, Zanetti ML, Santos MA. Quality of life in patients with diabetes mellitus before and after their participation in an educational program. Rev Esc Enferm USP. 2013; 47(2):344-9.

8. Nogueira PC, Rabeh SAN, Caliri MHL, Dantas RAS, Haas VJ. Burden of care and its impact on health-related quality of life of caregivers of individuals with spinal cord injury. Rev Latino-Am Enfermagem. 2012; 20(6):1048-56.

9. Almeida SA, Silveira MM, Espírito SPF, Pereira RC, Salomé GM. Assessment of the quality of life of patients with diabetes mellitus and foot ulcers. Rev Bras Cir Plást. 2013; 28(1):142-6.

10. Ware JE, Sherbourne CD. The MOS 36-item short-form health survey (SF-36). Conceptual framework and item selection. Med Care. 1992; 30(6):473-83. 
11. Souza ECS, Souza SA, Alves TOS, Gois CFL, Guimarães AMDN, Mattos MCT. Quality of life evaluation in patients with diabetes using the paid scale. Rev Min Enferm. 2012; 16(4):509-14.

12. Oliveira DC, Carvalho GSF, Stella F, Higa CMH, D’Elboux JV. Qualidade de vida e sobrecarga de trabalho em cuidadores de idosos em seguimento ambulatorial. Texto Contexto Enferm. 2011; 20(2):234-40.

13. Ministério da Saúde (BR). Conselho Nacional de Saúde, Comissão Nacional de Ética em Pesquisa. Resolução №466 de 12 de dezembro de 2012: aprova as diretrizes e normas regulamentadoras de pesquisa envolvendo seres humanos. Brasília: Ministério da Saúde; 2012.

14. Alves TOS, Souza AS, Souza ECS, Gois CFL, Guimaraes AMDN, Mattos MCT. Health-related quality of life of people with diabetes mellitus. Rev Min Enferm. 2013; 17(1):135-40.

15. Lima AP, Pereira DAG, Romano VF. Perfil sóciodemográfico e de saúde de idosos diabéticos atendidos na atenção primária. Rev Bras Ciênc Saúde. 2011; 15(1):39-46.
16. Morais GFC, Soares MJGO, Costa MML, Santo IBC. Conhecimento e prática dos diabéticos a cerca das medidas preventivas para lesões de membros inferiores. Rev Baiana Saúde Pública. 2009; 33(3):361-71.

17. Knuth A G, Bielemann RM, Silva SG, Borges TT, Del DGF, Kremer MM, et al. Public knowledge on the role of physical activity in the prevention and treatment of diabetes and hypertension: a population-based study in southern Brazil. Cad Saúde Pública. 2009; 25(3):513-20.

18. Braz JM, Silva MR, Gois CFL, Braz TM, Santos V, Silva LASM. Sintomas depressivos e adesão ao tratamento entre pessoas com diabetes mellitus tipo 2. Rev Rene. 2012; 13(5):1092-9.

19. Silva OC. La calidad de vida vinculada a la práctica de la actividad física regular. EFDeportes.com [periódico na Internet] 2010 [citado 2014 mar 30]; 15(150): [cerca de 8 p]. Disponível em: http://www.fen.ufg.br/revista/v10/n4/pdf/ v10n4a03.pdf

20. Ferreira FS, Santos CB. Health-related quality of life of diabetic patients seen by family health team. Rev Enferm UERJ. 2009; 17(30):406-11. 